\title{
PENGARUH MEDIA PUZZLE AKSARA JAWA TERHADAP KEMAMPUAN MENULIS AKSARA JAWA
}

\author{
Bamas Aprihadi Setiawan \\ SD N Sokanegara, Purwokerto, Indonesia \\ Email: setiawanbam@yahoo.com
}

\begin{abstract}
Javanese letter is an original Indonesian culture heritage. As a part its conservation, in 2 October 2009, UNICODE, as an institution under UNESCO, determined tha Javanese letter was equally admitted whit the other letter over the world such as Latin, Chinese, Arabic, and Japanese. However, this condition was not balance with the development the of the Javanese letter in Indonesia, especially by the Javanese people. This reserch was aimed at revealing more effect of the puzzle media of Javanese letter toward the student competence in writing Javanese Letter in class III A as the control class and class III B as the experimen class. All the student of class III are homogeny, therefore the sampling technique used Simple Random Sampling. The data collection in this reserch was by test. The data was calculated by normaly, homogeny test and t test. The result of student and was accepted therefore the puzzle media affter better toward the students competence in writing and reading Javanese Letter.
\end{abstract}

Key words: Writing Competence, Javanese Letter, Media of Puzzle

\section{LATAR BELAKANG}

Bangsa Indonesia merupakan negara yang kaya akan kebudayaan, salah satu kebudayaan yang masih dilestarikan adalah bahasa daerah. Hampir seluruh daerah yang ada di Indonesia memiliki bahasa daerah masing-masing yang sampai saat ini masih dilestarikan. Keberadaan Bahasa Daerah juga menjadi tanggung jawab masyarakat dan pemerintah provinsi, karena Bahasa Daerah merupakan bahasa yang dimiliki dan digunakan di daerah tertentu atau oleh masyarakat tertentu pula.

Bahasa Jawa merupakan salah satu bahasa daerah yang digunakan di Jawa, terutama Jawa Tengah, Yogyakarta dan Jawa Timur. Bahasa Jawa memiliki aturan perbedaan kosa kata dan intonasi berdasarkan hubungan antara pembicara dan lawan bicara, yang dikenal dengan unggah-ungguh aspek kebahasaan ini memiliki pengaruh sosial yang kuat dalam budaya Jawa, dan membuat orang Jawa biasanya sadar akan status sosialnya di masyarakat.

Salah satu kesadaran terhadap budaya yang beragam di Suku Jawa adalah penjagaan aksara Jawa. Aksara Jawa ini menjadi bukti nyata adanya zaman terdahulu sebelum adanya bangsa Indonesia. Sebagai wujud penjagaannya, pada tanggal 2 Oktober 2009, UNICODE sebuah lembaga di bawah naungan UNESCO, menetapkan aksara Jawa dan batik sebagai warisan asli budaya Indonesia (Tumoro, 2009). Menurut Tumoro, pengakuan tersebut diberikan setelah Ki Demang Sokowaten dari Yogyakarta pada 9 September 2007 silam mendaftarkannya ke Unicode, dengan pengakuan tersebut, masyarakat dapat meminta kepada programmer komputer untuk memasukkan aksara Jawa ke dalam font pada komputer. Dengan demikian aksara Jawa telah diakui dan setara dengan aksara lain di dunia yakni Latin, China, Arab, dan Jepang. Oleh 
karena itu, diperlukan upaya yang serius untuk menjaga dan melestarikan aksara Jawa sebagai salah satu warisan sejarah yang sangat bernilai. Di Jawa Tengah sendiri, pemerintah provinsi sudah mengeluarkan Surat Keputusan mengenai penetapan dan diberlakukannya kurikulum mata pelajaran bahasa Jawa yaitu SK Gubernur Jawa Tengan Nomor : 423.5/5/2010. Tujuan dikeluarkannya SK tersebut adalah untuk meningkatkan mutu pendidikan di Jawa Tengah, terutama dalam upaya penanaman nilainilai budi pekerti dan penguasaan Bahasa Jawa bagi siswa SD/SDLB/MI, SMP/SMPLB, SMA/SMALB/SMK/.

Kondisi saat ini menunjukan gejala semakin sedikitnya jumlah individu yang mampu berkomunikasi dengan menggunakan bahasa Jawa, baik secara lisan maupun tulisan dengan baik.Penelitian yang dilakukan oleh Sari Rahma (2013) mengatakan, penyebab rendahnya nilai bahasa Jawa dibandingkan dengan mata pelajaran lain adalah siswa yang mengalami kesulitan dalam membaca dan menulis aksara Jawa, bahkan bukan hanya siswa saja yang mengalami kesulitan membaca dan menulis aksara Jawa, akan tetapi hampir semua orang Jawa mengalami kesulitan membaca dan menulis aksara Jawa. Hal ini dapat menjadi indikator belum maksimalnya pembelajaran bahasa daerah (Jawa) di sekolah. Mukti Sutarman (aktivis serta pemerhati budaya

Jawa) dalam sebuah diskusi soal penggunaan bahasa Jawa di Kudus Sabtu (16/2/2013), salah satu kegagalan dalam pembelajaran Bahasa Jawa menurutnya adalah pola mengajar di sekolah yang terkesan jalan ditempat. Artinya guru yang mengampu pelajaran tersebut masih berpedoman pada silabus dan kurikulum.

Permasalahan lainnya adalah masih banyak guru bahasa Jawa baik di tingkat SD, SLTP dan SLTA yang belum memiliki kompetensi yang memadai. Ada empat aspek standar kompetensi guru, yakni penguasaan bidang studi, pemahaman peserta didik, penguasaan pembelajaran yang mendidik, dan pengembangan kepribadian dan keprofesionalan (Depdiknas, 2004). Kendala yang lainnya menurut Nanik $\mathrm{H}$ dalam penelitiannya yang berjudul "Pengajaran Bahasa Jawa di Sekolah" mengatakan jam pelajaran bahasa Jawa sangat minim bila dibandingkan dengan pelajaran yang lain, padahal materi dalam pelajaran bahasa Jawa sangat banyak, meliputi menulis aksara Jawa, unggahungguh, adat istiadat Jawa, dan yang lainnya.

Untuk mengatasi berbagai permasalahan mengenai pembelajaran bahasa Jawa tersebut, guru harus mampu menciptakan suasana pembelajaran bahasa Jawa yang menyenangkan, salah satunya adalah dengan menggunakan model permainan.Model permainan dalam pembelajaran tentunya dapat membuat siswa tertarik. Bermain mengandung aspek kegembiraan, kelegaan, kenikmatan yang intensif, bebas dari ketegangan atau kedukaan, bersifat memerdekakan jiwa (Rahmawati, 2010). Bermain merupakan salah satu cara membangkitkan semangat belajar siswa. Oleh karena itu diciptakan media pembelajaran dengan memunculkan permainan (game). Dengan hadirnya media pembelajaran yang menarik diharapkan dapat menciptakan suasana nyaman dan menyenangkan dalam proses pembelajaran.

Model permainan metode puzzle Aksara Jawa merupakan salah satu inovasi dalam pembelajaran Bahasa Jawa terutama materi menulis Aksara Jawa. Puzzle Aksara Jawa merupakan permainan merangkai huruf menjadi sebuah kalimat utuh. Dengan menyajikan bentuk pembelajaran yang berbeda mengenai Aksara jawa siswa diharapkan lebih tertarik untuk belajar mengenai Aksara Jawa dan siswa akan mengingat dan hafal bentuk dan dapat menuliskannya. Dari uraian tersebut, maka penelitian ini dilakukan untuk mengetahui pengaruh penggunaan Puzzle Aksara Jawa. 


\section{METODE PENELITIAN}

Metode yang dipakai dalam penelitian ini yaitu metode eksperimen. Menurut Sugiono (2010: 107) metode eksperimen diartikan sebagai metode penelitian yang digunakan untuk mencari pengaruh perlakuan tertentu terhadap yang lain dalam kondisi yang terkendalikan. Sampel yang digunakan dalam penelitian ini adalah seluruh siswa kelas III SD Negeri 2 Sokanegara, dimana dalam penentuan kelas kontrol dan kelas eksperimen dengan sampel acak sederhana (simple random sampling). Random Sampling adalah pengambilan sampel yang dilakukan secara acak atau random dari populasi, yang memungkinkan setiap individu berpeluang untuk menjadi sampel penelitian, dengan cara rendomisasi atau dengan cara melalui undian karena populasi dianggap seragam (homogen). Hasil undian yang

dilakukan adalah kelas III A dengan jumlah siswa 36 dijadika sebagai kelas kontrol dan kelas III B dengan jumlah siswa 37 dijadikan kelas eksperimen.

\section{HASIL PENELITIAN DAN PEMBAHASAN}

Menyatakan bahwa terdapat pengaruh kemampuan menulis aksara Jawa siswa lebih baik dengan menggunakan media puzzle aksara Jawa. Hal ini dibuktikan dengan hasil perhitungan dengan menggunakan uji dua pihak atau uji t untuk mengetahui pengaruh media puzzle aksara Jawa terhadap kemampuan menulis aksara Jawa. Media puzzle aksara Jawa berpengaruh lebih baik terhadap kemampuan menulis aksara Jawa siswa kelas III SD N 2 Sokanegara artinya siswa lebih terbantu dalam kemampuan menulis aksara Jawa, disebabkan karena proses pembelajaran di kelas eksperimen yang menggunakan media puzzle berlangsung dengan aktif. Siswa secara kompetisi harus menyelesaikan soal-soal menyusun aksara Jawa. Menurut Hamalik (1986: 23) Media yang diberikan kepada siswa akan memperjelas penyajian pesan dalam hal ini merupakan huruf Jawa serta mengatasi sikap pasif siswa, dengan menggunakan media akan menimbulkan kegairahan belajar siswa. Menurut Nani (2008) puzzle juga dapat membantu siswa untuk memperkuat daya ingat, dalam hal ini aksara Jawa yang disajikan dalam bentuk puzzle serta diberikan secara terus menerus terbukti mampu membantu siswa dalam mengingat berbagai bentuk aksara Jawa. Rata -rata kemampuan menulis aksara Jawa untuk kelas eksperimen yaitu 74,44.

Pembelajaran dikelas kontrol berbeda dengan pembelajaran yang dilakukan dikelas eksperimen, kondisi pembelajaran berlangsung secara langsung. Guru menjelaskan materi pembelajaran terlebih dahulu dan siswa langsung mengerjakan soal tanpa adanya proses bimbingan dan motivasi yang terus- menerus karena semua materi sudah dijelaskan di awal pembelajaran. Rata-rata nilai pos tes kemampuan menulis kelas kontrol yaitu 67,14. Jadi, penggunaan Media Puzzle aksara Jawa berpengaruh lebih baik terhadap kemampuan menulis aksara Jawa siswa SD Negeri 2 Sokanegara. Berdasarkan hasil uji pengolahan data dengan uji-t dan temuan dalam penelitian dapat disimpulkan bahwa terdapat pengaruh lebih baik penggunaan media puzzle aksara Jawa terhadap kemampuan menulis aksara Jawa siswa kelas III SD Negeri 2 Sokenegara. Media puzzle aksara Jawa mampu berpengaruh lebih baik terhadap kemampuan menulis, terbukti dari ratarata pos tes, diperoleh pada kelas eksperimen sebesar 74,44, sedangkan pada kelas kontrol sebesar 67,14. Sehingga membuktikan media puzzle aksara Jawa berpengaruh lebih baik terhadap kemampuan menulis aksara Jawa 


\section{SIMPULAN, SARAN DAN TINDAK} LANJUT

Berdasarkan hasil penelitian dan simpulan maka untuk perbaikan penelitian di masa yang akan datang ada beberapa saran yang dapat disampaikan antara lain:

1. Siswa diharapkan tetap memiliki rasa ingin tahu, aktif dan bekerja keras dalam belajar sehingga dapat meningkatkan kemampuan membaca dan menulis. Aksara Jawa merupakan warisan budaya daerah, dengan mempelajari aksara Jawa siswa juga melestarikan warisan budaya daerah.

2. Adanya motivasi yang sangat besar dari siswa dalam menggunakan media puzzle, sering kali siswa berebut untuk menggunakan media tersebut. Jadi perlu adanya peraturan yang lebih untuk mengatur siswa

3. 3. Pengaruh media puzzle aksara Jawa dapat diperoleh dan dapat terus dimanfaatkan dan ditingkatkan kualitasnya, maka diperlukan pengembangan lebih lanjut. Pengembangan ini dapat disosialisasikan atau dideseminasikan kepada guru-guru dan sekolah yang lain. Oleh karena itu direncanakan beberapa tindak lanjut sebagai berikut:

4. Media puzzle aksara Jawa dapat digunakan guru dalam materi aksara Jawa yang selanjutnya pada sekolah yang diteliti maupun di sekolah yang lain.

\section{DAFTAR PUSTAKA}

Misbach.2014.Pengertianpuzzle. [Online].

Tersedia:

http://www.kaskus.co.id/post/51f1 53598327cf5f53000003/. Diakses tanggal 9 Januari 2014

Riduwan. 2011. Belajar Mudah Penelitian

Untuk Guru-Karyawan dan

Peneliti Pemula. Bandung:

Alfabeta.
Sukardi. 2007. Metodologi Penelitian Pendidikan. Yogyakarta: Bumi Angkasa

Tarigan, Henry Guntur. 1982. Menulis sebagai suatu keterampilan berbahasa. Bandung: Angkasa. 